\title{
Review of the Arberesh Lexicology
}

\author{
Dr. Evis Hudhëra \\ University "Ismail Qemali", Vlore \\ Department of Albanian Language and Literature
}

\begin{abstract}
Arberesh people in their multicentury efforts in order to keep their national identity, have tried not to be absorbed into their language, cultural and religious assimilation in the Italian speaking environment. Our study relates to the world of these Arberesh people and without a doubt their connection in one way or the other, direct or indirect, with the world of overseas, the motherland. Even though centuries away, the Arberesh people have never denied their heritage, language, habits, customs and psychology. In various libraries in and out the Arberesh environment, in and out of Italy (like Denmark) there are manuscripts of dictionaries developed from Arberesh who were directly linked to the Arberesh or Albanian Word. In these dictionaries are registered a very valuable wealth taken orally from the people themselves (in Arberesh speaking environments), from the Arberesh literature, in publications, from the publications in Albania or any other lexicographic published works. The lexicographic Arberesh tradition is rich and it has an important place in the overall national Albanian lexicography. This tradition comes with published and unpublished dictionaries. According to the information that comes from the researchers F. Altimari, M. Mandala, academic publishing etc., that are more than 20 . It is a fact that today is boing done a great work to publish the works of manuscripts. The researcher Gezim Gurga in the preface of the critical publishing Albanian-Italian dictionary of Da Leçe (Francesco Maria Da Lecce Dittionario italiano - Albanese, 1702) lets us know that the publishing is a part of the University of Palermo, "that foresees, among others, the critical publishing of all the works of the manuscripts of the Sicily Arberesh, such as The Albanian-Italian Dictionary and the Etymologic Dictionary, designed by Nikollë Keta, various manuscripts of Albanian-Italian and Italian Albanian dictionaries of Dara family etc.". The designed dictionaries of the spoken Arberesh language, the published and unpublished ones may be grouped typologically and chronologically. The model of a scientific adduction and a very informative presentation is given by Prof. Mandala in his work "Philological studies for the romantic Arberesh literature".
\end{abstract}

Keywords: Albanian-Italian Dictionary, the arberesh lexicology, Arberesh language, Italian language

\section{Introduction}

Arberesh people, in their multi century efforts to preserve their national identity, have achieved to save the linguistic, cultural and religious assimilation in the Italian speaking environment. The researcher Zhan de Misel states that "the ones who resided in Sicily and the Southern provinces of Italy, the ancient Magna Graecia, created stratification. They preserved their origin culture, the Albanian culture, sometimes good and sometimes bad, and the Byzantine ritual or the Latin ritual (being it traditional, or acquired later), without losing anything they were integrated very well, but remained out of any type of assimilation."1

According to the same researcher "apart from "integration" it never became synonym of "assimilation", even for the Arberesh of the Latin belief. A proud nation, identified, such as, it never subjected to the surrounding environment, only to present this identity. Emigration made these people democrats, (they were anarchist within them) with a pride that radiates a type of arrogance."2

Our study relates to the world of these Arberesh and without a doubt the world abroad, with their motherland. As even after all these centuries, they have never denied their heritage, the language, customs, and psychology. Again, according to Zhan de Misel: "Five centuries have gone by since the beginning of immigration, and even though the immigrants are integrated in the hosting structures in a similar Christian environment, but distinguishable from the language and rituals, they have remained even today the heirs of the Albanians of the $15^{\text {th }}$ century.

\footnotetext{
1 Jean De Miceli, An overall review of the arberesh problem, in Fotaq Andrea, Arberesh of Italy, 1413-2007, Tirana, 2012, pg. 470

2 Jean De Miceli, An overall review of the arberesh problem, in Fotaq Andrea, Arberesh of Italy, 1413-2007, Tirana, 2012, pg. 478
} 
The ritual more from the language, the nature more from the culture thus interfered with all their weight of Illyrian atavism on the path of an assimilation that only of this fact remains partially failed." 1

Zhan de Miseli also writes that "the Arbëresh never forgot the drama of their birth.

"Their Mother" had died at birth. The orphans remained in the hands of mixed unions, but have always felt in their veins the blood of martyrs of the homeland and of faith, the blood of their mixed ancestors. "And in the first place, this coming through the centuries, this mischief of the birth drama, this resistance to the assimilating environment appears in arberisht, in the Albanian word, kept and transmitted from generation to generation. In order not to forget this, there were many works from Arberesh sons, by documenting the continuance and non detachment from the Albanian nation and transmitting the message of non extinction.

Natali Klaje writes: "Among westerners, a special place should be given to the arberesh intellectuals of Italy as they were in research of their origine of their "Nation"... some writing personalities that came out of the arberesh colonies of Sicily and Calabria started to build an Albania. They did this in two ways: on one hand, through publishing in Italian language, on the origin, history and the language of the Albanian nation and on the other hand though a poetry and literature corpus with creative inheritance, or with collections of folk songs." 2

In various libraries, inside and outside the Arbëresh environment, inside and outside of Italy, there are manuscripts of many dictionaries written from Arberesh in relation to the Arberesh or Albanian word. In these dictionaries, a precious asset was recorded, picked up in Arberesh speaking environments, from Arberesh literature, from publicity, from editions on the other side of the sea, or from published lexicographic works.

The importance of dictionaries is irreplaceable and unique: they enumerated lexo-semantic subjects, and provided grammatical data, thus serving as a reflection of the Arberesh language and beyond, and creating opportunities to undertake studies for lexical semantic wealth, phonetic features, grammatical, dialectal, historical processes, sociolinguistic phenomena (especially phenomena of bilingualism and competition of Arberesh and Italian speech, the borrowing process and that of preservation of Albanian language), ethno linguistic, etc.

Arberesh's lexicographic tradition is rich and has an important place in Albanian nationwide lexicography. It comes with published and unpublished dictionaries. According to information coming from scholars F. Altimari, M. Mandala, academic editions, etc., there are over 20 dictionaries. It is a fact that today is a commendable work for the publication of manuscripts.

The scholar Gëzim Gurga in the Preface of the Albanian-Italian dictionary, of Da Lece lets us know that the publishing is a part of the project of University of Palermo, "which foresees the critical thinking of all the remained works in manuscripts from the Arberesh of Sicily such as the Italian-Albanian Dictionary and The Etymologic Dictionary, developed by Nikolle Keta, various types in manuscripts of vocabularies in Italian -Albanian-Albanian of Dara family etc.."

The developed dictionaries for the Arberesh speech may be grouped typologically and chronologically. The model of a scientific preview and a very informative presentation gives Prof Mandala in his before mentioned work.

According to the language/languages whose the subject belongs to, the dictionaries are divided into bilingual and monolingual dictionaries. The bilingual dictionaries are in Italian-Albanian (arberesh- and in Albanian (arberesh)-Italian (Nikolle Keta has developed an Albanian-Italian dictionary).

The bilingual dictionaries just like in Albania have preceded the practical of development of the monolingual dictionaries. The scholar M. Mandala accepts that dictionaries are developed as bilingual repertoires and the practical need to learn Italian, and they were developed "usually from Italian missionaries who with their bilingual vocabulary aimed to help new colleagues".

While the monolingual dictionaries from the Arberesh world and abroad are three, one explanatory, one phraseological and onomastic-topomastic.

According to the goal of subject explanation, they are divided into general and etimologic dictionaries.

\footnotetext{
1 Jean De Miceli, An overall review of the arberesh problem, in Fotaq Andrea, Arberesh of Italy, 1413-2007, Tirana, 2012, pg. 472

${ }^{2}$ Nathalie Clayer, Italian-arberesh in research of their origin, in Fotaq Andrea, Arberesh of Italy, 1413-2007, Tirana, 2012, pg. 499-500
} 
In another view, the dictionaries may be seen chronologically developed. The scholar M. Mandala, supported from a group of criteria, divides the lexicographic tradition of Arberesh in two major time periods:

a. the first period: the end of $X V I I^{\text {th }}$ century - end of $X X^{\text {th }}$, that is characterized from casual lexical materials and the printed format of dictionaries.

b. Second period: the end of XXth century -today, a period characterized from the organized work, planned and directed to harvest the lexical wealth and especially form the quality feature that the development of computerized and programming sciences have brought in this process, through the digitalization of distribution of dictionaries in the electronic format.

As bilingual dictionaries we are going to mention:

1. The dictionary developed from Nilo Catalano, which unfortunately is lost and comes as information only by the notes of Zef Skiroi

2. In 1702 Father Francesco Maria Da Lecce developed Dittionario Italiano - Albanese, a work that for three centuries remaind in manuscript, and as it was stated earlier was published in 2009 under the care of scholar G. Gurga.

3. In 1763 Nikolle Keta finished developing the work Leksiko liti, kthiellë arbërisht, which is published in 2006, under the care of Giuseppina Cerniglia and an Introduction of scholar M. Mandala.

4. The beginning of XIXth century, as precedes M. Mandala, is lexicographically identified from the work of Andrea Dara who left manuscripts that "witness the efforts to develop a bilingual Albanian-Italian dictionary" and Francesco Crispi Glaviano.

5. We cannot leave without mentioning the given contribute to the Arberesh lexicography from the scholar Dhimter Kamarda and his brother Zef Kamarda. According to Mandala, from them we have a lexical collection which "even though is not complete, testifies for a high scientific and lexicographic level".

6. There is information that the poet Zef Skiroi worked in developing a bilingual dictionary Albanian -Italian and Italian Albanian.

7. The first half of the $X X^{\text {th }}$ century is identified with the lexicographic work of the priest Pal Skiroi, with the ongoing and committed work of Gaetano Petrota, with the work of Francesca Bidera Opingari, the only arberesh woman who was a lexicographer. etc..

As etymological dictionaries we can mention: The Etymologic Dictionary of Gjergj Guxeta. The author when talks about the heritage and nature of Albanian language, confronts it with "the languages of classical culture such as Greek and Latin, but also with other European languages such as Italian, French, German and Spanish".

1. The first etymological dictionary and this manuscript come from N. Keta, developed in 1779. It is found in the Royal Library of Copenhagen under the title Lessico italian'e macedone. Always, according to Mandala "in in the work of Keta we clear the weakest parts, we have in front of us a complete novelty masterpiece, from the view of history and lexicography of the Albanian language and also from the history of the albanological culture in general.

2. It is widely known the help of Dhimiter Kamarda for the etimological lexicography, even though he did not develop a true dictionary. In the work Saggio di Grammatologia Comporata", in the Appendix, there is a dictionary with hundreds of words that were studied etymologically.

3. The only true lexicographic work developed before the middle of $X X^{\text {th }}$ century from the linguist Marco La Piana is the etymologic dictionary, a voluminous work found in the Archive of the Arberesh Seminar of Palermo. According to Mandala, The dictionary, which is not published yet, has thousands of files, and each of them contains the phonetic transcription and the etymological explanation of the word".

The year 1963 brought events for Arberesh lexicography and the Albanian one too. It is published the Dictionary of the Italy Arberesh, with 19.000 basic words, with synonyms in Italian, as explanations, with hundreds of synonyms in Albanian, and numerous illustrations from the artistic literature. The work is republished in 2000 , completed with the bilingual dictionary in Italian-Arberesh language. 
The end of the $X X^{\text {th }}$ century to this day is directly related to the use and the role of the computer in the lexicographic practice. The lexicographic computerization in arberesh community is identified with the name of the academic Altimari. The BETA project he drafted represents the most advanced tendency of today's albanology. Thanks to this project, according to the scholars, it will be possible to codify the extremely large lexical material resulting from the electronic collection of the literary amount and soon there will be a historical dictionary of the Arberesh language of Italy.

According to academic scholar Altimari, there has been over 20 years of work focused more on systematic lexicon dialectal collection, relying, on the one hand, on corpora texts "reconstructed" philologically and summarized in manuscripts discovered in Italian magazines of the 19th century; on the other hand, in the methodical research work of students who began collecting the general lexicon and the special lexicon based on questionnaires used for atlas, such as EAL (Europae Atlas Linguarum), ALI (Atlante Linguistico Italiano), LAA (Linguistic Albanian Atlas)"1.

According to the academic also, in the framework of the project ARBËR, which aims to collect all the written literature and oral evidence of Arberesh's heritage and memory, are created the foundations of the Arberesh Lexicographic Archive, which has emerged as the convergence of the lexicon of the authors who came after the elaboration of texts with concordances, and the lexicon of Arberesh speech.

The lexicographic tasks before the Arberesh scientific world comes through the words of this scientist: "We are confident that with the new technological tools available to us we can create a large and updated lexical database, which as far as we as arberesh need is a necessary condition to concretize the Modular Project of a Great Arberesh Dictionary. This dictionary we as Albanologs in Italy have a scientific advantage in the coming years to face the great challenge that we face after the adoption of laws in favor of our minority, having the opportunity to give to the Arbëresh community the great linguistic richness that we inherited and it is waiting to be recognized and appreciated from the didactic view, and to be available to our people and scientists."

A model of the lexicographic work done in the Arberesh world through the centuries is enough to be finalized with a statement of Vicenco Dorsa for whom the nation is a entirety of people who accept an origin, one language, docs and traditions on their own and "Happy be the author that raises a monument to his country".

\title{
References
}

[1] F. M. da Lecce, Dizionario italiano-albanese [Italian-Albanian Dictionary], 1702

[2] L. la Monte Giove, Dizionario italiano-albanese [Italian-Albanian Dictionary], 1848

\begin{abstract}
${ }^{1}$ Among the theses of this type we mention: a) under the care of prof. Solano: Giovanni Battista Rennis, La poesia popolare italo-albanese di Lungro [The folk arberesh poetry of Ungra] (academic year 1976-'77);:Anna Casolaro, La comunità albanese di S.Demetrio Corone nelle sue tradizioni popolari [Arberesh community of Sant Mitri and its folk traditions] (academic year 1976-'77); Angiolina Cataldi, La parlata e la letteratura popolare di S. Basile [The spoken arberesh and folk literature of Saint Vasili] (academic year 1979-80); Anna Maria Trotta, S. Sofia d'Epiro: parlata e letteratura popolare [Saint Sofi: The spoken arberesh and folk literature] (academic year 1979-'80); Domenica Ferrari, Uno studio fonologico e morfologico sulla parlata albanese di Frascineto [A phonological and morphological on the arberesh speech of Frasnita] (academic year 1980-'81); Francesco Marchianò, La parlata di Spezzano Albanese e la sua letteratura popolare [The spoken arberesh of Spexana and folk literature] (academic year 1980-'81); Maria Pina Cardillo, La parlata albanese di S. Sofia d'Epiro [The spoken arberesh of Saint Sofi] (academic year 1981-'82); Rosa Nico, Studio fonologico e morfologico sulla parlata di Cervicati [A phonological and morphological on the arberesh spoken form of Çervikati] (academic year 1981-82); Maria Carmela Rugliano, La parlata di Civita [The spoken arberesh in Civeti] (academic year 1983-'84); Rina Tucci, Uno studio fonologico e morfologico sulla parlata albanese di Castroregio [A phonological and morphological on the arberesh spoken form of Kasternexh] (academic year 1984-85); Nicolina Gradilone, Aspetti fonologici e morfologici della parlata di Macchia Albanese [A phonological and morphological on the arberesh spoken form of Maqi] (academic year 1983-'84); Maria Laurito, Spezzano Albanese: profilo di una continuitá poetica nella diaspora [Spexana: the profile of a poetrical continuance in Diaspora] vol. I (pp. 411) e II (pp. 141 + appendice) (academic year 1987-'88); b) under the care of prof. Trumper: Antonietta Campagna, La parlata albanese di Acquaformosa [The spoken arberesh of Firmosa] pp.321 (academic year 1987-'88); Lucia Santo, La parlata arbereshe di San Giorgio Albanese [The spoken arberesh of Mbuzat] (academic year 1987-'88); c) under the care of prof. Guxeta: Pinuccia Stamati, Uno studio fonologico e morfologico sulla parlata albanese di Plataci [A phonological and morphological on the arberesh spoken form of Pllaten], pp. 324 (academic year 1986-'87).

${ }^{6}$ F. Altimari, Puna kërkimore e zhvilluar në Universitetin e Kalabrisë në fushën e leksikografisë arbëreshe: drejtime dhe rezultate
\end{abstract}


[3] Francesco P. Rossi, Vocabolario italiano-epirotico [Italian-Albanian Dictionary], Rome, 1866, 353 pg.

[4] Dhimitër Kamarda, Albanian-Epyrian Alphabetical Dictionary, Livorno, 1869.

[5] Antonio Bussetti, Vocabolario italiano-albanese [Italian-Albanian Dictionary], Shkoder, 1911, 1147 pg.

[6] Angelo Leotti, L'albanese parlato, cenni grammaticali; vocabolario albanese-italiano, italiano-albanese, proverbi, dialoghi [The spoken Albanian, grammar indicators, Albanian-Italian dictionary, Italian-Albanian Dictionary, proverbs, dialogues], Milano, 1916, $425 \mathrm{pg}$.

[7] Adamo Lacalendola, Dizionario della lingua albanese toska, parte italiano-albanese [Albanian Toske Dictionary (Italianalbanian part)], Bari, 1931, 155 pg.; 1936, 179 pg.

[8] Fulvio Cordignano, Dizionario albanese-italiano ed italiano-albanese (II nuove "Jung", parte albanese-italiano) [ItalianAlbanian and Albanian-Italian dictionary, Albanian-italian part], Milano, 1934, $339 \mathrm{pg}$.

[9] Angelo Leotti, Dizionario albanese-italiano [Albanian-Italian dictionary], Rome, 1937, $1710 \mathrm{pg}$.

[10] Adamo Lacalendola, Dizionario albanese-italiano [Albanian-Italian dictionary], Bari, 1937, 181 pg.

[11] Fulvio Cordignano, Dizionario italiano-albanese (Italian-Albanian dictionary), Shkoder, 1938, 757 pg.; Bologne, 1968.

[12] 25 years emptiness

[13] Emanuele Giordano, Dizionario degli Albanesi d'Italia - Dictionary of Arberesh of Italy (Albanian-italian), Bari, 1963,597 pg.

[14] C. B. Massolini, U. Buttafava, Vocabolario albanese-italiano [Albanian-Italian dictionary], Rome, 1979, 355 pg.; Italy, 1992 (25 000 words); Tirana, 2001.

[15] Sofron K. Prençe, Italian-Albanian Dictionary, Palermo, 1984.

[16] Antonio Bellusci, Phraseologic Dictionary of Albanians of Italy and Greece [Dizionario fraseologico degli albanesi d'Italia e di Grecia: testo originale nella parlata albanese, trad. in lingua italiana, inglese e francese], Cosenza, 1989, $262 \mathrm{pg}$.

[17] Paola Guerra, Alberto Spagnoli, Italian-Albanian dictionary, Albanian-Italian (12 000 words), Milano, 1993, 221 pg.

[18] (Dictionary without a publishing year) Dizionario dei cognomi e sopranomi in Calabria (Dictionary of the nouns and adjectives in Calabria), Ravene, pg. 1-40, 297-328. 
